http://jmscr.igmpublication.org/home/ ISSN (e)-2347-176x ISSN (p) 2455-0450 crossref DOI: https://dx.doi.org/10.18535/jmscr/v7i8.123

\title{
Prospective Study of Short Term outcome of Medial open Wedge High Tibial Osteotomy Using Modified Arthrax Plate (Puddu Plate)
}

\author{
Authors \\ Dr Malik Naseer Ahmad ${ }^{1}$, Dr Rajinder Singh ${ }^{2}$, Dr Mohmmad Farooq Bhatt ${ }^{3}$, \\ Dr Abdul Ghani ${ }^{4}$, Dr Sheikh Khalid Nissar ${ }^{5}$, Dr Imtiyaz Ahmad Beigh ${ }^{6}$, \\ Dr Tanveer Ahmad Bhatt ${ }^{7}$ \\ ${ }^{1,5,6,7} \mathrm{Jr}$. Resident, ${ }^{2,4}$ Professor of Orthopaedics, ${ }^{3}$ Asst. Professor
}

\begin{abstract}
Introduction: High tibial osteotomy (HTO) is a well-established procedure for treatment of unicompartmental osteoarthritis of knee. HTO is a favoured choice of treatment for isolated unicompartment arthritis in patients who are aged less than 60 years. The biomechanical rationale for HTO in patients with unicompartmental osteoarthritis of knee is unloading of the involved joint compartment by correcting the malalignment and redistributing the stresses on the knee joint.The factors associated with good long-term results include: tibiofemoral angle > 8 valgus, body weight no > 132\% of ideal body weight, age < 60 years, purely unicompart mental arthrosis, ligmantous stability, pre-operative range of motion knee $>90^{\circ} \&$ Ahlbak's grade $1 \& 2$.

Method: This prospective study of 32 patients was conducted in the department of orthopaedics at govt. Medical college, Jammu from May 2016 to December 2018, who satisfy the inclusion criteria.

Result: In our study 13 patients (40.63\%) had excellent results, 18 (56.25\%) had good results and $1(3.12 \%)$ had fair results. None of the patients in our study had poor results. Out of 32 patients 7 $(21.88 \%)$ were males and $25(78.12 \%)$ were females, the age of patients ranged from 42 to 57 years. the average range of motion of the involved knee in pre-operative period was 131.56 degree with range of 100-150 degree, With improvement in ROM at the final follow-up was 133.9 degrees with a range from 110 to 150 degrees. The pre-operative HSS score ranged from 56-72 with a mean of 63.312, at follow-up of 9 months HSS ranged from 69-89 with a mean of 83.46. There was an average increase of 20.01 in the score at final follow-up.

Conclusion: High tibial osteotomy is a safe, reliable procedure in unicompartmental osteoarthritis of knee. There is significant improvement in the pain and function which allows the patient to squat and sit cross legged which is very important in our community for social and religious activities. It is a valuable option in our community where majority of patients are unwilling for unicompartment or total knee arthoplasty.
\end{abstract}

\section{Introduction}

Osteoarthritis is the most common articular disease of the developed world and a leading cause of chronic disability, mostly as a consequence of the knee OA and/or hip OA
(Grazio S et al 2009). The most common deformity in patients with osteoarthritis of knee is varus malalignment position which causes stress to be concentrated medially accelerating degenerative changes in medial part of the joint 
and progression of osteoarthritis (Gomol AH et al. 2016). There is as yet no drug that can modify the effect of osteoarthritis (Solomon $\mathbf{L}$ et al. 1988). The goal of treatment is to alleviate the signs and symptoms of the disease and, if possible, to slow its progression. Surgery is indicated when the patient's symptoms accord with the physical and radiological findings and all conservative treatments have exhausted. The fundamental principles of osseous deformity correction were defined by Friedrich Pauwels in 1964 and Paul Maquet in 1976. Mark Coventry in 1965 published his technique for closed wedge osteotomy $^{[3]}$, which became the gold standard for many years. High tibial osteotomy (HTO) is a well-established procedure for treatment of unicompartmental osteoarthritis of knee (Billing A et al. 2000). HTO is a favoured choice of treatment for isolated unicompartment arthritis in patients who are aged less than 60 years (Brinkman JM et al. 2008). The biomechanical rationale for HTO in patients with unicompartmental osteoarthritis of knee is unloading of the involved joint compartment by correcting the malalignment and redistributing the stresses on the knee joint (Dabov G et al.). The factors associated with good long-term results include: tibiofemoral angle $>8$ valgus, body weight no $>132 \%$ of ideal body weight, age $<60$ years, purely unicompartmental arthrosis, ligmantous stability, pre-operative range of motion knee $>90^{\circ} \&$ Ahlbak's grade $1 \& 2$ (Amendola A et al. 2010; Dabov G. D et al.; Insall JM, et al. 1984).

\section{Material and Method}

This prospective study of 32 patients was conducted in the department of orthopaedics at govt. Medical College, Jammu from May 2016 to December 2018 .All the patients were admitted on OPD basis. A detailed clinical history and examination was done. The examination included findings on inspection and palpation as, intercondylar distance with ankles touching or intermalleolar distance with knees touching, testing for lateral ligaments with varus or valgus stress, testing for menisci and cruciate ligaments and patellofemoral joint examination by patellofemoral compression test (Zohlen test). Complete neurovascular status assessment was done. The patients who were found to have unicompartmental osteoarthritis with knee pain not relieved by conservative management and who satisfy the inclusion criteria (Table no. 1), willing for the surgical procedure were selected and their consent obtained. Pre-operative planning is done by Miniaci method. Normally there is valgus alignment of 5 to 8 degrees in tibiofemoral angle as measured by radiograph taken in the weight bearing position. The amount of correction of the arthritic knee needed to achieve a normal angle is calculated and an additional 3 to 5 degrees overcorrection is added to achieve approximately 10 degrees of valgus. Anteroposterior weight-bearing alignment view is used for pre-operative planning. To determine the weight-bearing line, two separate lines are drawn from the center of the femoral head and the center of ankle towards the Fujisawa point. Fugisawa point is point on lateral condyle of tibial, the width of the tibial plateau medial to this point is $62.5 \%$ of the total tibial plateau width.

High tibial opening wedge osteotomy is done using Puddu plate (10 $\mathrm{mm}$ or $12 \mathrm{~mm}$ ) according to the desired wedge to be created.

TABLE 1

\section{i) Inclusion Criteria}

\begin{tabular}{|l|l|}
\hline 1. & Age 20-60 years. \\
\hline 2. & $\begin{array}{l}\text { Unicompartmental (medial) osteoarthritis on } \\
\text { weight bearing radiograph with a } \\
\text { corresponding varus deformity. }\end{array}$ \\
\hline 3. & $\begin{array}{l}\text { Pain and disability resulting from } \\
\text { osteoarthritis that significantly interfere with } \\
\text { activities of daily living. }\end{array}$ \\
\hline 4. & $\begin{array}{l}\text { Patients who needed less the 20 degrees of } \\
\text { deformity correction. }\end{array}$ \\
\hline 5. & $\begin{array}{l}\text { Patients with medial compartment } \\
\text { osteoarthritis who have flexion contracture } \\
\text { of less than 15 degrees with range of motion } \\
\text { of 90 degrees or more. }\end{array}$ \\
\hline 6. & Body mass index (BMI) less than 30. \\
\hline
\end{tabular}




\section{ii) Exclusion Criteria}

\begin{tabular}{|l|l|}
\hline 1. & $\begin{array}{l}\text { Age less than } 20 \text { and greater than } 60 \text { years } \\
\text { of age. }\end{array}$ \\
\hline 2. & $\begin{array}{l}\text { Osteoarthritis involving more than one } \\
\text { compartment. }\end{array}$ \\
\hline 3 & $\begin{array}{l}\text { Severe joint destruction (Kellegren and } \\
\text { Lawrence stage 4) }\end{array}$ \\
\hline 4. & $\begin{array}{l}\text { More than 15 degrees of flexion contracture } \\
\text { and/or less than 90 range of motion. }\end{array}$ \\
\hline 5. & Lateral tibial subluxation of more than 1cm. \\
\hline 6. & $\begin{array}{l}\text { Greater than 20 degree of deformity } \\
\text { correction needed. }\end{array}$ \\
\hline 7. & Infective and inflammatory arthritis. \\
\hline 8. & Significant peripheral vascular disease. \\
\hline 9. & Poor skin condition \\
\hline 10. & BMI >30 \\
\hline
\end{tabular}

\section{Result}

In our study, the age of patients ranged from 42 to 57 years with an average age of presentation was 50.63 years. Out of 32 patients 7 (21.88\%) were males and $25(78.12 \%)$ were female with male to female ratio of 0.28 . Of the total11 had involvement of left knee and 21 had involvement of right knee. Most of the patients had pain localized to the medial side of the knee aggravated by walking and stair climbing. The duration of symptoms ranged from 1 year to 8 years with mean duration of 3.625 years. In our study the BMI ranged from 20.8 to 28.4 with an average BMI of 25.46. For patients with MCOA, the average range of motion of the involved knee in pre-operative period was 131.56 degree with range of 100 to 150 . Most of the patients included in our study had grade 2 and 3 osteoarthritis. The pre-operative HSS score ranged from 56-72 with a mean of 63.312, the range of pre-operative a TFA was 5-12 varus with an average of 7.56 degree varus and pre-operative mechanical axis deviation (MAD) ranged from $20-45 \mathrm{~mm}$ medially with an average of $32 \mathrm{~mm}$.Time taken for surgery ranged from 70 minutes to 110 minutes. The mean duration of surgery was 90.78 minutes and the mean hospital stay was 4.187 days with a range of 2-5 days. Range of motion of the operated knee was started on the second postoperative day. Nonweight bearing crutch walk was demonstrated and started on second post-operative day. Weight bearing as tolerated was started at 06 weeks. The time of full weight bearing in our study ranged from 08-12 weeks, with a mean of 8.44 weeks. Average range of motion at the final follow-up was 133.9 degrees, with a range from 110- 150 degrees. The aTFA at final follow up ranged from 2-8 degree valgus with an average 5.5 degrees valgus. Mechanical axis deviation ranged from 5$15 \mathrm{~mm}$ lateral with an average of $10.25 \mathrm{~mm}$. The HSS score at 9 follow-up months ranged from 6989 with a mean of 83.46 . There was an average increase of 20.01 in the score at final follow-up. In our study 13 patients (40.63\%) had excellent results, 18 (56.25) had good results and $1(3.12 \%)$ had fair results. None of the patients in our study had poor results

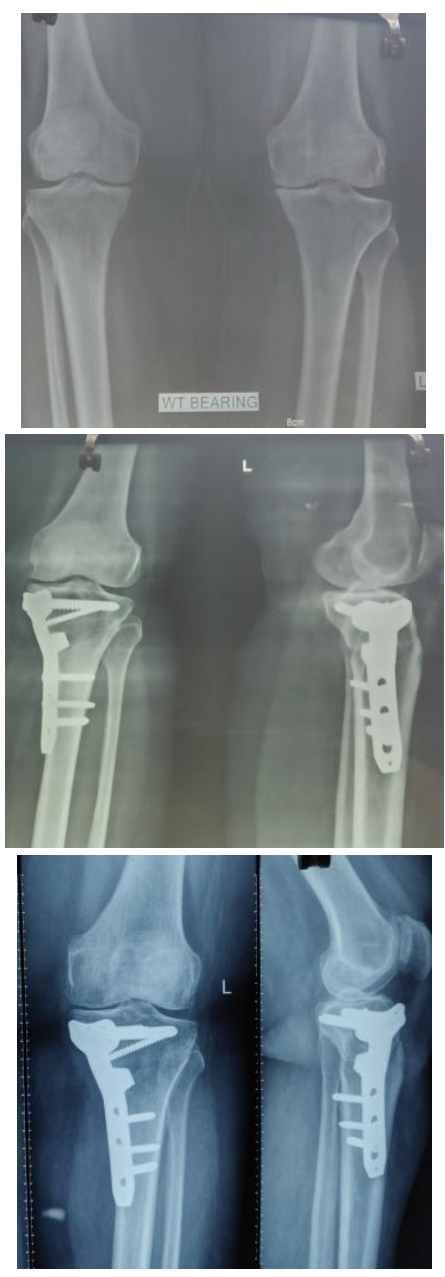

X-ray of patient at initial presentation, at 3 month and 9 month follow up respectively. 

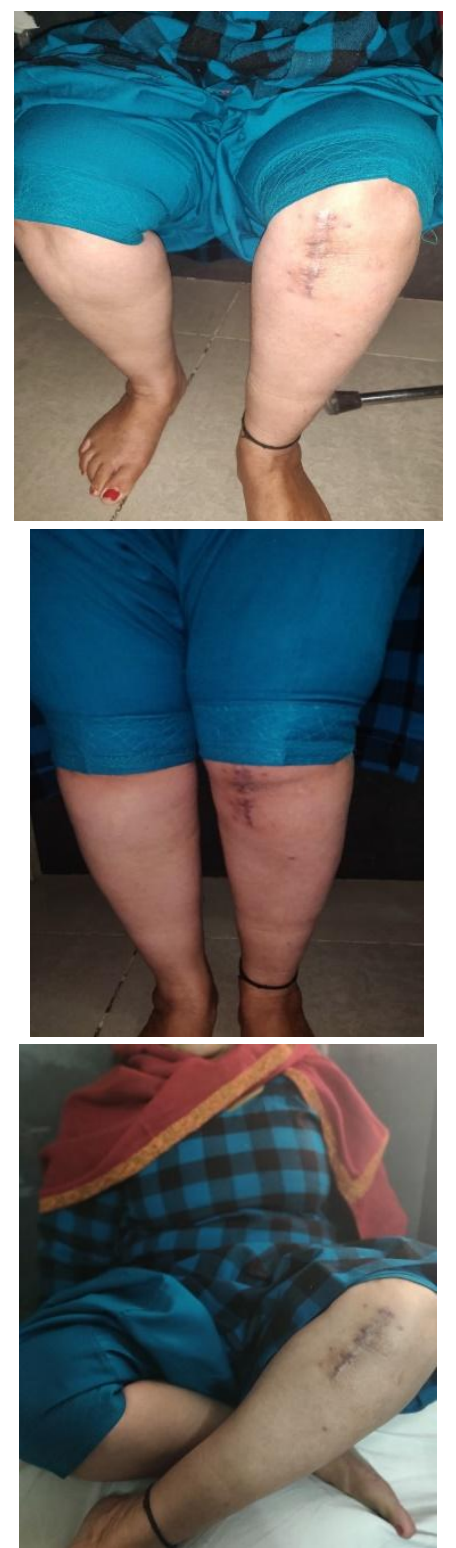

Pictures of the patient taken on final outcome with sitting standing and squatting

\section{Discussion}

Medial open wedge osteotomy has been more popular recently. The advantages are the ability to correct the alignment in two planes (coronal and sagittal), no need for fibular osteotomy, little risk of peroneal nerve injury, no limb shortening, use of a single cut with no need to detach the muscles, no bone loss, easier conversion to arthroplasty, and ability to adjust the amount of correction during surger. The modified conventional arthrex plate (Puddu plate) helps to stablize high tibial osteotomy from the medial side. Its specific locking system and metallic wedge provides stability and obviate the need of the graft as well.
High tibial osteotomy gives adequate pain relief in younger patients, delaying the need for knee replacement.

\section{Number of Patients}

\begin{tabular}{|l|c|c|c|}
\hline Series & $\begin{array}{c}\text { Phillip Niemeyer } \\
\text { et at 2008 }\end{array}$ & $\begin{array}{c}\text { Werner Kolb } \\
\text { et al 2009 }\end{array}$ & $\begin{array}{c}\text { Present } \\
\text { Study 2018 }\end{array}$ \\
\hline No. of Patients & 88 & 51 & 32 \\
\hline
\end{tabular}

The number of patients in our study was 32. It was less than the number in other studies on HTO with medial open wedge technique. The reason for having fewer patients in our study being our study was conducted for less time compared to other studies.

\section{Side Involved}

\begin{tabular}{|l|c|c|c|}
\hline Series & $\begin{array}{c}\text { M Pfahler et } \\
\text { al(2008) }\end{array}$ & $\begin{array}{c}\text { Tomisha k et } \\
\text { al (2004) }\end{array}$ & $\begin{array}{c}\text { Present study } \\
\text { (2018) }\end{array}$ \\
\hline Side & & & \\
\hline Right & 60 & 40 & 21 \\
\hline Left & 44 & 35 & 11 \\
\hline
\end{tabular}

Right side was involved more in our study. Other two studies also showed right side dominance. In our study 21 patients had right and 11 patients had left side involvement.

Age

\begin{tabular}{|l|c|c|c|}
\hline $\begin{array}{l}\text { AGE:- } \\
\text { Series }\end{array}$ & $\begin{array}{c}\text { Niemeyer et } \\
\text { al. (2008) }\end{array}$ & $\begin{array}{c}\text { Werner K et } \\
\text { al. (2009) }\end{array}$ & $\begin{array}{c}\text { Present study } \\
(\mathbf{2 0 1 8})\end{array}$ \\
\hline Mean in years & 49 & 47.3 & 50.63 \\
\hline
\end{tabular}

The mean age in our study was 50.63 years. It was comparable to other two studies. Youngest patient in our study was44 years and the eldest one was 57 year old.

\section{Sex Distribution}

\begin{tabular}{|l|c|c|c|}
\hline Series & $\begin{array}{c}\text { Tomihisa K et } \\
\text { al. (2004) }\end{array}$ & $\begin{array}{c}\text { Mehmet A et al. } \\
\text { (2006) }\end{array}$ & $\begin{array}{c}\text { Present } \\
\text { study 2018 }\end{array}$ \\
\hline Male/Female & $11 / 42$ & $13 / 47$ & $7 / 25$ \\
\hline Ratio & 0.26 & 0.78 & 0.28 \\
\hline
\end{tabular}

25 out of 32 patients were females. Numbers of females in our study were similar to other two studies as well. The male to female ratio in our study was 0.28 , it was 0.26 in study conducted by Tomihisa et al (2004) and 0.78 in the study conducted by Mehmet Asik et al (2006).

Body Mass Index (BMI)

\begin{tabular}{|l|c|c|c|}
\hline Series & $\begin{array}{c}\text { Niemeyer et } \\
\text { al. (2008) }\end{array}$ & $\begin{array}{c}\text { Phillip S et al. } \\
\mathbf{2 0 1 8}\end{array}$ & $\begin{array}{c}\text { Present } \\
\text { study 2018 }\end{array}$ \\
\hline BMI & 27.2 & 27.2 & 25.46 \\
\hline
\end{tabular}


Body mass index in our study was an average of 25.46 and was comparable to other studies. We had a total of seven patients with BMI of more than 30, however they were excluded from our study and given other treatment options. The highest BMI in our study was 28.4 and the lowest BMI in our study was a patient with BMI of 20.8.

\section{Radiological Grade}

\begin{tabular}{|l|c|c|c|}
\hline $\begin{array}{l}\text { (Kellegren and } \\
\text { Lawrence grading) } \\
\text { series grade }\end{array}$ & $\begin{array}{c}\text { J Vojtassak } \\
\text { et al. (2000) }\end{array}$ & $\begin{array}{c}\text { S Akizuki } \\
\text { et al.(2008) }\end{array}$ & $\begin{array}{c}\text { Present study } \\
\mathbf{2 0 1 7}\end{array}$ \\
\hline 1 & $7(15 \%)$ & $0(0 \%)$ & 00 \\
\hline 2 & $20(42.5 \%)$ & $09(6 \%)$ & $12(37.5 \%)$ \\
\hline 3 & $20(42.5 \%)$ & $53(33 \%)$ & $20(62.5 \%)$ \\
\hline 4 & $0(0 \%)$ & $0(0 \%)$ & $0(0 \%)$ \\
\hline Total knees & $\mathbf{4 7}$ & $\mathbf{2 5}$ & $\mathbf{3 2}$ \\
\hline
\end{tabular}

Most of patients in our studies were grade 2 and grade 3 osteoarthritis. 37.5 percent in grade 2 and 64.25 percent in grade 3 , were operated up on in our study. None of the patients with grade four arthritis was included in our study as in other two studies.

\section{Anatomical Tibiofemoral Angle (aTFA)}

\begin{tabular}{|l|c|c|c|}
\hline Series & $\begin{array}{c}\text { Mehmet A } \\
\text { et al. (2006) }\end{array}$ & $\begin{array}{c}\text { Niemeyer } \\
\text { et al. (2008) }\end{array}$ & $\begin{array}{c}\text { Present } \\
\text { study 2018 }\end{array}$ \\
\hline $\begin{array}{l}\text { Pre-operative aTFA } \\
\text { (varus) }\end{array}$ & 5.7 & 1.9 & 7.56 \\
\hline $\begin{array}{l}\text { Final follow-up } \\
\text { aTFA (valgus) }\end{array}$ & 6.5 & 7.2 & 5.5 \\
\hline
\end{tabular}

Anatomical tibiofemoral angle on average at final follow up was 5.5 (valgus). It was comparable to other two studies.

\section{Mechanical Axis Deviation (MAD)}

For patients with medial compartment osteoarthritis, preoperative MAD ranged from 20$45 \mathrm{~mm}$ medially with an average of $32 \mathrm{~mm}$ MAD

\begin{tabular}{|l|c|c|c|c|c|c|}
\hline $\begin{array}{l}\text { Series } \\
\text { MAD }\end{array}$ & \multicolumn{2}{|c|}{$\begin{array}{c}\text { Mehmet Asik et } \\
\text { al. (2006) }\end{array}$} & \multicolumn{2}{|c|}{$\begin{array}{c}\text { P Robinsoet al. } \\
\text { (2011) }\end{array}$} & \multicolumn{2}{|c|}{$\begin{array}{c}\text { Present } \\
\text { Study }\end{array}$} \\
\hline & $\begin{array}{c}\text { Pre-op } \\
\text { (medial) }\end{array}$ & $\begin{array}{c}\text { Final } \\
\text { follow- } \\
\text { up } \\
\text { (lateral) }\end{array}$ & $\begin{array}{c}\text { Pre-op } \\
\text { (medial) }\end{array}$ & $\begin{array}{c}\text { Final } \\
\text { follow- } \\
\text { up } \\
\text { (lateral) }\end{array}$ & $\begin{array}{c}\text { Pre-op } \\
\text { (medial) }\end{array}$ & $\begin{array}{c}\text { Final } \\
\text { follow- } \\
\text { (lateral) }\end{array}$ \\
\hline & 36 & 5.09 & 31.25 & 3.9 & 32 & 10.2 \\
\hline
\end{tabular}

\section{Range of Motion (ROM)}

\begin{tabular}{|l|c|c|}
\hline Series & $\begin{array}{c}\text { Tarun K et al. } \\
(\mathbf{2 0 1 5})\end{array}$ & $\begin{array}{c}\text { Present Study } \\
\mathbf{2 0 1 8}\end{array}$ \\
\hline Pre. Op ROM & $140(116-154)$ & $131.56(120-150)$ \\
\hline Post op. ROM & $140(115-154)$ & $133.9(110-145)$ \\
\hline
\end{tabular}

The average range of motion in our study preoperative was 131.56 and post-operative at final follow up was 133.9. The pre and postoperative range of motion of knee were comparable. Same was observed in other study.

\section{Complications}

\begin{tabular}{|l|c|c|c|}
\hline $\begin{array}{l}\text { Complications I } \\
\text { Series Complication }\end{array}$ & $\begin{array}{c}\text { Mehmet A et } \\
\text { al. (2006) }\end{array}$ & $\begin{array}{c}\text { Tarunkuma } \\
\text { r et al. } \\
\text { (2015) }\end{array}$ & $\begin{array}{c}\text { Present } \\
\text { study 2018 }\end{array}$ \\
\hline $\begin{array}{l}\text { Superficial wound } \\
\text { infection }\end{array}$ & 2 & 1 & 4 \\
\hline Tibial plateau fracture & 1 & 1 & 2 \\
\hline Implant infection & 1 & 0 & 0 \\
\hline $\begin{array}{l}\text { Compartment } \\
\text { syndrome }\end{array}$ & 0 & 0 & 0 \\
\hline $\begin{array}{l}\text { Deep venous } \\
\text { thrombosis length }\end{array}$ & 2 & 0 & 03 \\
\hline $\begin{array}{l}\text { Limb } \\
\text { (lengthening) }\end{array}$ & 0 & & 0 \\
\hline
\end{tabular}

None of our patients had implant infection or deep venous thrombosis as reported in other studies.

4 of our patients had superficial wound infection which was managed on intravenous antibiotics and settled within one week.

2 of our patients had tibialplateu fracture. They were advised for delayed weight bearing however both united within 8 weeks. 3 of our patient had limb lengthening of 0.5 to $1 \mathrm{~cm}$, however there was no limp.

\section{HSS Score and Final Results}

\begin{tabular}{|l|c|c|c|}
\hline $\begin{array}{l}\text { Series Mean } \\
\text { HSS score }\end{array}$ & $\begin{array}{c}\text { MehmatAsik } \\
\text { et al (2006) }\end{array}$ & $\begin{array}{c}\text { Werner } \\
\text { Kolb et } \\
\text { al (2009) }\end{array}$ & $\begin{array}{c}\text { Present } \\
\text { study } \\
\mathbf{( 2 0 1 8 )}\end{array}$ \\
\hline Pre-operative & 61.3 & 65.8 & 63.32 \\
\hline Final follow-up & 88.07 & 92.2 & 83.46 \\
\hline
\end{tabular}

The preoperative HSS score on average in our study was 63.32 , and postoperative score at final follow-up was 83.47

There was an average increase of 20.04 in HSS score in our study, which was comparable to other studies.

\section{Final HSS Score (Percentage)}

\begin{tabular}{|l|c|c|}
\hline Series Result & $\begin{array}{c}\text { Werner Kolb et al } \\
(\mathbf{2 0 0 9 )}\end{array}$ & Present study \\
\hline Excellent & $20(57 \%)$ & $13(40.63 \%)$ \\
\hline Good & $12(24 \%)$ & $18(56.25 \%)$ \\
\hline Fair & $4(08 \%)$ & $01(3.12 \%)$ \\
\hline Poor & $5(10 \%)$ & $00(0 \%)$ \\
\hline
\end{tabular}

40.63 percent of our patients had excellent, 56.25 percent had good and 3.12 percent had fair results. None of our patents had poor results. 
Conclusion

$>$ High tibial osteotomy is a safe, reliable procedure in unicompartmental osteoarthritis of knee.

$>$ There is significant improvement in the pain and function which allows the patient to squat and sit cross legged which is very important in our community for social and religious activities.

It is a valuable option in our community where majority of patients are unwilling for unicompartment or total knee arthoplasty.

\section{References}

1. Aglietti P, Buzzi R, Vena LM, Baldini A, Mondaini A. The Journal of Knee Surgery [01 Jan 2003, 16(1):21-26.

2. Alex E, Staubli Carlo, De Simoni, Reto Babst, Phillip Lobenhoffer. Department of orthopaedics Luzern, Switzerland. Injury 2003, vol.34,suppl.2

3. Amendola A. And Bonasia D. E. Results of high tibial osteotomy: review of literature. International orthopaedics. Volume 34, Number 2/ February,2010.

4. Brinkman JM, Lobenhoffer P, Agneskirchner JD, Staubli AE, Wymenga AB, van Heerwaarden RJ. Osteotomies around the knee: patient selection, stability of fixation and bone healing in high tibial osteotomies. J Bone Joint Surg Br. 2008; 90(12):1548-57.

5. Billing A, Scott DF,CamargoMP,Hofmann AA,. High tibial osteotomy with a calibrated osteotomy guide,rigid internal fixation and early

6. Conventry MB (1965). Osteotomy of the upper portion of tibia for degenerative arthritis of knee: a preliminary report . JBJS Am 47:984

7. Dabov G. D. Miscellaneous Nontraumatic Disorders. Campbell's Operative Orthopaedics. $11^{\text {th }}$ ed. P999 - 1019 ;Crockarell JR jr, Guyton JL. Arthroscopy of the Knee. Campbell's Orthopaedics. 11 th ed. P 241299. 21.1

8. Gomol AH, Angele P, Condello V, et al . Load distribution in early osteoarthritis, Knee surg sports TraumatolArthrosc 2016;24;1815-25.motion .Long term followup.JBJS Am 2000;82;70-9. 20.

9. Grazio S, Balen D. Obesity: Risk factor and predictors of osteoarthritis. LijecVjesn. 2009;131:22-6.

10. Insall J, Shoji H, Mayer V (1974). High tibial osteotomy. A five year evaluation. $\mathbf{J}$ Bone Joint Surg Am 56:1397-1405

11. Insall JM, Joseph DM, Msika C (1984) High tibial osteotomy for varusgonarthrosis: A long term follow-up study. JBJS Am 66:1040-1048.

12. Karl Stoffel, Gwidon Stachowiak, Markus Kuster. November 2004Volume 19, Issue 9, Pages 944-950 - Clinical biomechanics, 2004 - Elsevier

13. Mehmet Asik, Cengiz Sen, Bulent kilic et al. High tibial osteotomy with paddu plate for treatment of varusgonoarthrosis. Knee Surg Sports TraumatolArthrosc (2006)14;948-954

14. M. Phafler, $\mathbf{C}$ Lutz, $M$ Maier, J Housdorf. .Long term results of high tibialosteotomy.Actachirbelg ,2003,103,603-606.

15. Phillip Niemeyer, MD, Wolfgang Koestler, MD; Christiankaehny, MD; et al. Result of open wedge high tibial osteotomy by medial plate fixater for medial compartment arthritis. The journel of Arthroscopic and related surgery, vol 24, no 7(July) 2008; pp. 796-804.

16. Phillip Schuster, MD, Markus Geblein et al. Ten year results of medial open wedge high tibialosteotomy. The American journel of sports medicine;1-9vol $\mathrm{xx}$ ,no.X,Xxxx. 
17. S Akizuki, A Shibakawa et al. Long term outcome of high tibialosteotomy.JBJS (Br) ;2008;90-B;592-6.

18. Solomon L., Warwick D.J., Nayagam S.Osteoarthitis. Apley's System of Orthopaedics and Fractures. $8^{\text {th }}$ ed. P77-86 \& p472-473. 1. Felson DT: Epidemiology of knee and hip osteoarthritis. Epidemiol Rev 1988; 10: 1-28. 2) Das SK,

19. Tomihisa Koshino, Takuji Yoshida, Yuki Ara.et al ; Fifteen to twenty years follow up results of high tibial osteotomy for osteoarthritic knee. The Knee 11 (2004) 439-444.

20. Tarunkumar et al (2015). journel of indianorthopaedic rheumatology/julyaugust 2015 (1)(1) 6-11.

21. Vojtassak J, Seliga J Bratisl Lek Listy 2001; 102 (10): 470-472 2nd Department of Orthopaedics, Faculty of Medicine, Comenius University and General Hospital Ruzinov, Bratislava High tibial osteotomy and debridement of the knee joint in treatment of varoticgonarthrosis. Address for correspondence: J. Vojtassak, MD,
PhD, 2nd Dept of Orthopaedics, General Hospital Ruzinov, Ruzinovska 26, SL-826 06 Bratislava, Slovakia. Phone/Fax: +421.2.43338748 2nd Department of Orthopaedics, Faculty of Medicine, Comenius University and General Hospital Ruzinov, Bratislava, Slovakia.bll@ fmed.uniba.sk.

22. Werner Kolb, MD; Hanno Guhlmann, MD; Christoph Windisch, MD; Klaus Kolb, MD; Heiko Koller, MD; Paul Grützner, MD.J Bone Joint Surg Am, 2009 Nov 01; 91 (11): 2581 -2588.

23. Wright, John M. MD; Crockett, Heber C. MD; Slawski, Daniel P. MD; Madsen, Mike W. MD; Windsor, Russell E. MD. Journal of the American Academy of Orthopedic Surgeons: July/August 2005 Volume 13 - Issue 4 - p 279-289.83.

24. P.M. Robinson, M.C.Papana et al. High tibial osteotomy in medial compartment osteoarthritis and varus deformity using the taylor spatial frame.;Strat trauma limb Recon (2011)6;137-145. 